d. COLUMBIA |SIPA

Center on Global Economic Governance

CGEG-CDEP WORKING PAPER SERIES

CGEG-CDEP WP No. 9

Asset Stripping, Rule of Law and Firm

Survival: The Hoff-Stiglitz Model and Mass

Privatization in Montenegro

Matjaž Koman, Milan Lakičević, Janez Prašnikar and Jan Svejnar

November 2013

do COLUMBIA |SIPA

Center for Development Economics and Policy 


\title{
ASSET STRIPPING, RULE OF LAW AND FIRM SURVIVAL: THE HOFF-STIGLITZ MODEL AND MASS PRIVATIZATION IN MONTENEGRO
}

\author{
Matjaž Koman $^{\mathrm{a}}$ \\ Milan Lakičević ${ }^{b}$ \\ Janez Prašnikar \\ Jan Svejnar ${ }^{\mathrm{d}}$
}

November 2013

\begin{abstract}
a. University of Ljubljana, Institute for South-East Europe, Slovenia, Department of Economics, Ljubljana, Slovenia

b. University of Podgorica, Montenegro, Department of Economics, Podgorica, Montenegro

c. Department of Economics, Ljubljana, Slovenia

d. Columbia University, New York, USA; University of Ljubljana, CERGE-EI, CEPR, IZA. Email svejnar@columbia.edu
\end{abstract}

\begin{abstract}
We provide the first test of the Hoff and Stiglitz (2004) model predicting whether and under what conditions mass privatizations are accompanied by asset stripping. In addition to directly testing the theory, we also tackle an important policy-oriented issue of why a large number of efficient firms disappeared during mass privatization in a booming economy of Montenegro. Econometrically, we present the first study to look at firms that disappeared during a mass privatization transition, improving upon prior studies that focused only on existing firms and assumed away survival bias. Our analysis suggests that asset stripping and firm disappearance were present, and that asset stripping was a likely reason for the loss of efficient firms. We show that because more productive firms were liquidated, it is important to model survival bias in the selection of firms remaining in samples when estimating the effects of privatization or other ownership changes. We also show that one needs to distinguish between true start-ups and liquidated firms that re-appear as start-ups. In the absence of the rule of law, many firms that appear to have disappeared were in fact appropriated by managers and politically connected individuals.
\end{abstract}

Acknowledgements: Prašnikar's and Koman's research in this paper was in part supported by the Slovenian Research Agency's grant no. J5-227. Svejnar benefitted from a grant from the Grant Agency of the Czech Republic (Grant no. P402/10/2130). The authors would like to thank Aaron Baum for helpful comments and editorial assistance.

JEL Classifications:

L33: Comparison of Public and Private Enterprises; Privatization; Contracting Out

P24: Socialist Systems and Transitional Economies: National Income, Product, and Expenditure;

Money; Inflation

P31: Socialist Enterprises and Their Transitions 


\section{INTRODUCTION}

Privatization of state-owned firms has been a key feature of the transition from communism to capitalism, and from the outset the general expectation was that privatization would improve the performance of firms and thus also the transition economies. The early surveys of privatization in transition economies showed positive or mixed results. ${ }^{1}$ The most recent survey by Estrin, Hanousek, Kocenda, and Svejnar (2009) indicates, however, that while privatization to foreign owners has a positive effect on firm performance, privatization to domestic owners has a much less positive effect in Central and East Europe, and that the effect is on average zero or even negative in the Commonwealth of Independent States (CIS). A leading explanation for the limited or nonexistent positive performance effect of privatization to domestic owners is stripping of enterprise assets by managers.

Hoff and Stiglitz (2004) develop the first model of asset stripping and identify conditions under which asset stripping may be observed. Yet, despite the importance of the Hoff-Stiglitz model, there has been no formal empirical test of its predictions. Campos and Giovannoni (2006) develop a second model of asset stripping and econometrically test their model's predictions. Campos and Giovannoni (2006) are handicapped, however, in that they do not have information about stateowned enterprises - i.e., about firms whose assets were presumably stripped. In the absence of this direct information, the authors infer the extent of asset stripping from an answer provided by general managers of new start-up firms. In particular, they use as their proxy for an asset stripping variable the answer that these managers provided to the question: "How much of your capital equipment came from state enterprises which helped found this firm?" This approach is ingenious but obviously rough. The key problem is that the capital equipment in question might or might not have been stripped from the state enterprises. Moreover, the question is excessively narrow because asset

\footnotetext{
${ }^{1}$ The earlier studies are reviewed for instance in Megginson and Netter (2001) and Djankov and Murell (2002). They vary from finding no systematic performance effect (Bevan, Estrin, and Schaffer, 1999) to noting that a positive effect probably dominates (Megginson \& Netter, 2001), to concluding that the overall effect is positive (Carlin, Fries, Schaffer, and Seabright, 2001; Djankov \& Murrell, 2002; Shirley and Walsh, 2000).
} 
stripping includes items other than just equipment - e.g., profit, raw materials, and semi-finished and finished goods. The issue remains as to what extent this indirect measure reflects actual asset stripping.

The state of the literature is therefore such that there is a relatively rough test of the Campos and Giovannoni theoretical model and, to the best of our knowledge, no formal test of the predictions of the Hoff-Stiglitz theoretical model.

In this paper, we contribute to the literature by testing directly the two key predictions of the Hoff-Stiglitz model with respect to asset stripping, as well as addressing twin policy-oriented puzzle: the disappearance of a large number of originally state-owned firms during mass privatization, despite a rapidly growing economy. In our empirical analysis, we find support for the key predictions of the Hoff-Stiglitz asset stripping model, the hypothesis that asset stripping is the cause of the limited survival of these firms and that, counter to predictions from standard economic theory, more rather than less productive firms were liquidated. This finding points to the need to model the endogenous exit of firms when one estimates the effects of privatization of firm performance. Our results also indicate that one needs to distinguish between true start-ups and liquidated firms that reappear as de novo (start-up) firms.

To carry out our analysis, we collected a unique dataset of all 225 firms in Montenegro that went through mass voucher privatization beginning in 2001. A particularly interesting feature of our data set from the standpoint of possible asset stripping is that during this period Montenegro may be characterized as having had a weak rule of law and while the total number of firms in the country was growing, the total number of firms in our sample decreased markedly. Almost one-half of the 225 firms going through privatization went bankrupt or were liquidated, often reappearing as private firms with influential managers or politically linked individuals as new owners.

Given this background, our empirical strategy is to use data on the state-owned firms that went into mass privatization and infer the presence of asset stripping from the characteristics of the 
firms that survived versus those that did not. We are hence able to use a more direct approach than Campos and Giovannoni (2006). As we discuss below, our econometric estimates support the key predictions of the Hoff-Stiglitz model. In particular, firms that had assets and whose assets were easier to strip (firms that were more productive and smaller) were also the firms that were more likely to go bankrupt or be liquidated in the privatization period. ${ }^{2}$ We do not find support for two more ad hoc hypotheses advanced in the context of the Hoff-Stiglitz model, namely that more indebted firms were less likely to survive and firms with more long-term assets as a proportion of total assets were more likely to survive. We surmise that this is due to different institutional settings in Russia (which inspired the Hoff-Stiglitz model) and Montenegro.

Econometrically, we are the first to look at firms that disappeared - because of data limitations, firm-level studies generally ignore the survival bias that may be quite serious. Our results show that more productive firms were liquidated, a finding that points to the need to model the selection of firms into the sample when one estimates the effects of ownership changes. ${ }^{3}$ Our results also indicate that one needs to distinguish between true start-ups and liquidated firms that re-appear as de novo (start-up) firms.

The paper is organized as follows. In the next section we describe the relevant features of the institutional context. In Section 3 we outline the Hoff-Stiglitz model and derive the predictions and hypotheses used in our research. In Section 4 we discuss our data and empirical strategy. In Section 5 we present our empirical results and in the last section we conclude.

\footnotetext{
${ }^{2}$ This phenomenon could be observed in many transition economies. However, the more decentralized characteristic of the Yugoslav economy before privatization gave managers more information about their firm and its environment, which they used in the process of privatization. Anecdotal evidence as well as rather limited literature on this issue (e.g., Gregurek (2001), Gregorič (2002), Cerović and Dragutinović Mitrović (2007), Koman and Hadži Vasileva - Markovska (2007), Koman et al. (2011)) thus suggest that the model of management appropriation was common in the countries of former Yugoslavia, including Macedonia, BIH, Croatia and Serbia. The Slovenian situation was different in that the process of management buy-outs escalated only before the current crisis (see, for example, Prašnikar, Svejnar (2007), Domadenik et al. (2008) and Bole et al. (2012)).

${ }^{3}$ This finding complements that of Gupta, Ham and Svejnar (2008), who show with Czech data that better performing firms were privatized first and ignoring this selection leads to biased estimates of the effects of privatization in existing studies.
} 


\section{INSTITUTIONAL CONTEXT}

Montenegro became a member state of Yugoslavia after World War I and joined the Socialist Federal Republic of Yugoslavia under Josip Broz Tito's rule after World War II. Over the 45 years of its duration, the socialist Yugoslav economy was defined by social ownership of property, resulting in the widespread perception that property was owned by all citizens (Prašnikar and Prašnikar, 1986). Moreover, a complicated market-based planning mechanism with worker participation in management gradually determined resource allocation and income distribution (Prašnikar and Svejnar, 1991), leading to widespread perception that official rules did not have to be fully respected.

Interestingly, Montenegro introduced different models of privatization before the main process - known as mass voucher privatization - started in $2001 .^{4}$ A striking characteristic was that each privatization attempt resulted in the failure of a large number of firms. In June 2001, all citizens over the age of 18 received vouchers and 225 Montenegrin public and private limited companies were included in the mass voucher privatization plan. As in Russia's Big Bang privatization, which occured in the absence of the rule of law, the initial conditions in Montenegro contributed to low transparency of the privatization process and weak investor protection. Indeed, both the Bankruptcy Law of 2002 and the legal system as a whole permitted property manipulation. In the presence of slow institutional transformation, enthusiasm in the early 2000s to build an open market economy permitted asset stripping, as well as the rapid concentration of ownership of many firms by few influential individuals.

\footnotetext{
${ }^{4}$ The start of the privatization process in Montenegro was connected with 1989 Yugoslav legislation called the Federal Legal Act of Social Capital, which was based on an internal privatization model that emphasized social ownership transfer to companies' employees. In the beginning of 1990, Yugoslavia collapsed and this law did not have a significant influence on the ownership transformation process in Montenegro. The first privatization legislation in Montenegro was introduced in 1992, and its main goal was to estimate the value of company capital and define the privatization method. The result was a transfer of social ownership to state funds (60 percent of companies' ownership) and employees (40 percent of companies' shares). The next milestone in the Montenegrin privatization process was in 1996 when new legislation, the Privatization Law of 1996, was introduced. The main emphasis of this Law was on the privatization of the direct and indirect ownership by the state and the introduction of the idea of mass voucher privatization. Construction of the legal framework for the privatization process was continued in 1999 when Amendments to the Privatization Law were adopted and the mass voucher privatization plan was introduced (Vukotić, 2001).
} 
The tourist company Ski-centar Durmitor, once one of the flagship companies in Montenegro, provides an illustrative example. Due to mass voucher privatization, its workers received $26.96 \%$ ownership of the firm and investors, using their privatization vouchers, bought the rest. The former manager leased a substantial part of the company's property (hotel, ski lifts, restaurants, and shops) to his own, newly formed company, called New Ski-centar Durmitor, and later filed for bankruptcy protection for the old firm. In the following years, the bankruptcy receiver sold the old company's remaining property (land and buildings) to private investors at extremely low prices. Recently, the New Ski-centar Durmitor also declared liquidation due to its high indebtedness and most of the property was sold to a newly formed company, again owned by the former manager. ${ }^{5}$

Because of the lack of transparency and state control during the privatization process, 90 percent of adult Montenegro citizens characterized the process as "badly managed." They expressed dissatisfaction with the role of government, parliament and trade unions in the privatization process. Only the media were perceived to have played a positive role by reporting the manipulations that were taking place in the privatization process (Karadžić and Jovović, 2008).

\section{THEORETICAL FRAMEWORK AND HYPOTHESES}

In this section, we combine the essence of the institutional setting described above with the Hoff-Stiglitz theoretical model to obtain testable predictions about asset stripping. Hoff and Stiglitz (2004) develop a static model of asset stripping and the demand for the rule of law, basing it on Russia's experience with "Big Bang" privatization of state-owned enterprises (that was similarly accompanied by significant asset stripping in the absence of rule of law). Their model economy consists of agents who have control rights over enterprises. Each agent chooses between two actions to maximize the expected value of his wealth: 1) strip the assets of the enterprise and appropriate the value; 2) build enterprise value by making an irreversible investment to increase the value of the

\footnotetext{
${ }^{5}$ See, Žabljački oriđinali uništili turizam, Vijesti, February 4, 2011, (pp.6) for a detail description of this case.
} 
enterprise. Agents who strip assets actively hamper (or are indifferent to) the establishment of the rule of law because it may reduce their ability to strip. In contrast, agents who build value demand the rule of law because it permits agents to conclude enforceable contracts.

The model permits one to derive testable predictions. Let $\mathrm{x}$ be the fraction of agents in the economy who oppose the establishment of the rule of law and 1-x denote the constituency for the rule of law. Note that this implies the probability of establishing the rule of law is a decreasing function of x. Agents differ in their abilities to strip enterprise assets versus create enterprise value. An agent's type with respect to this ability is represented by $\theta$, where agents with a higher value of $\theta$ strip assets better, but are less productive in investing.

The model may be characterized by the two curves depicted in Figure 1: 1) the switch line and 2) the stripping ability curve. The switch line is downward sloping and gives combinations of $\mathrm{x}$ and $\theta$ for which the agents are indifferent between building value and stripping assets. Combinations of $\mathrm{x}$ and $\theta$ below the lines reflect agent types that build value, while those above the line reflect agents that strip assets. Thus, any factor that shifts the switch line downward will result in a higher probability of asset stripping. In the Montenegrin context, for example, widespread pessimism about the emergence of the rule of law at the beginning of mass voucher privatization presumably shifted the switch line down.

The stripping ability curve gives, for each value of $\theta$, the fraction of agents whose ability is greater than or equal to that value. If the factors that determine the ability to strip assets and build value are normally distributed in the population of agents, the stripping ability curve will tend to have the S-shape depicted in Figure 1.

Equilibria occur at the intersection of the two curves. As may be seen from Figure 1, multiple equilibria are possible, with stable equilibria being given by the intersections where the slope of the stripping ability curve is steeper than that of the switch line ( $x^{*}$ in Figure 1). Because the probability of establishing the rule of law is a decreasing function of $x$, equilibria further to the right yield a 
smaller probability of establishing the rule of law, and hence a higher probability of asset stripping (and lower probability of building enterprise value). As may be seen from Figure 1, factors that shift the stripping ability curve upward result in a higher probability of asset stripping (higher value of $\mathrm{x}$ ) at a stable equilibrium. Moreover, a large enough upward shift may eliminate the presence of a good equilibrium altogether, resulting in greater asset stripping. Note, a downward shift in the switch line will have a similar effect to an upward shift in the stripping ability curve (a higher probability of asset stripping).

\section{Insert Figure 1 about here}

We combine the essence of the institutional setting described previously with the Hoff-

Stiglitz theoretical model to obtain two ceteris paribus predictions about asset stripping:

Prediction 1: Firms that were more efficient before mass voucher privatization were more likely to be subject to asset stripping and hence more likely to go bankrupt or be liquidated.

Prediction 1 reflects the fact that managers and politically connected individuals possessed better information about firm value than others and in the weak legal system they focused on stripping assets (appropriating value) of valuable firms during mass privatization. ${ }^{6}$ It is to be noted that Prediction 1 stands in contrast to the prediction from the standard economic theory, which would suggest that more efficient firms are more likely than others to survive because of their greater ability to compete.

Prediction 2: Firms that were larger before mass voucher privatization were less likely to be subject to asset stripping and hence more likely to survive.

\footnotetext{
${ }^{6}$ See also, Gupta, Ham and Svejnar (2008) for description of the cherry pick effect in the context of timing of privatization.
} 
Prediction 2 reflects the assumption that even in an imperfect legal setting it is harder to strip assets of large (visible) firms. The Montenegrin institutional setting was conducive to this behavior. Before voucher privatization, bank loans were administratively rationed to large state-owned companies. Subsequently, these firms were more closely monitored by banks and state authorities (see Table 1 for leverage by firm ownership and size).

In addition to the predictions that are derived from their theoretical model, Hoff and Stiglitz also offer two relatively ad hoc hypotheses about factors that might increase managers' ability to strip assets. In the Montenegrin context, they may be expressed as:

Hypothesis 1: Firms that were more indebted (leveraged and mortgaged) before mass voucher privatization were less likely to survive.

Hypothesis 2: Firms with more long-term assets as a proportion of total assets before mass voucher privatization were less liquid and hence more likely to survive. ${ }^{7}$

In stating the two hypotheses, Hoff and Stiglitz draw on the institutional setting of Russia's privatization, as well as the intuitive notion that asset stripping would increase in situations where the firm is more liquid, all else equal.

Note that the factors mentioned in Predictions 1 and 2, as well as Hypotheses 1 and 2, are likely to increase an agent's ability to strip and thus shift up the stripping ability curve. A large enough upward shift can of course eliminate the "good equilibrium."

\section{DATA AND SUMMARY STATISTICS}

As mentioned above, mass voucher privatization took place in Montenegro in June, 2001 when all citizens over the age of 18 received vouchers and 225 Montenegrin public and private limited companies were included in the mass voucher privatization plan. Before the process started,

\footnotetext{
${ }^{7}$ In particular, the more easily the commodities requiring little processing can be extracted from the assets, more likely is the stripping of resources.
} 
the principal owners of the 225 companies were state funds and employees. In particular, three state funds (Development Fund, Pension Fund, and Employment Fund) had on average a 55 percent ownership stake, while employees had on average 27.6 percent. Direct state ownership was low at 4.4 percent, the representation of private investors was only 10 percent, and other owners held on average 3 percent (Vukotić, 2001). ${ }^{8}$

For all the 225 firms that participated in the 2001 mass voucher privatization we obtained accounting data from income statements and balance sheets, as well as data on the ownership structure, for the pre-mass privatization period $1998-2000 .{ }^{9}$ Together with information from the Register of Legal Entities in Montenegro from year 2008, we are able to determine which of the 225 firms that entered mass voucher privatization plan survived until 2008 (survivors) and which did not (non-survivors). We use these 2008 data on survivorship and the 1998-2000 firm-level data on revenues, long-term assets, debt/assets ratio, leverage, employment, ownership structure, estimated TFP, and mortgages to test the Hoff-Stiglitz predictions and hypotheses.

We present descriptive statistics in Table 1, which shows the characteristics of firms that did not survive mass voucher privatization in comparison to those that did survive. Firms that did not survive were on average smaller in terms of revenues, number of employees, value of assets, and fixed capital compared to firms that survived, and the differences are statistically significant. The TFP estimate shows that firms that did not survive were on average significantly more productive than firms that survived. ${ }^{10}$ On the other hand, there were no statistically significant differences among the survivors and non-survivors in their average leverage or possession of a mortgage. The long term assets/total assets ratio was significantly higher in firms that survived than those that did not survive, and the share of state ownership (direct and direct plus indirect) was higher in survivor

\footnotetext{
${ }^{8}$ Mass voucher privatization ended in 2002. Thirty-seven enterprises out of 227 were fully privatized using this method, 135 were more than $90 \%$ privatized, and 33 were more than $70 \%$ privatized. In 19 large-sized companies the government retained a controlling share The government also prepared a number of large-sized companies for sale to the highest bidder (a strategic investor) by selling either assets or equity shares on tenders. (Ekonomski fakultet Podgorica, 2011).

${ }^{9}$ The source for this data was publication of Privatization Council of Montenegro (Savjet za privatizacijo, 2001).

${ }^{10}$ The TFP measure is based on the error component in a panel fixed effect estimation.
} 
than non-survivor firms. These statistics are suggestive of the type of endogenous exit implied by Predictions 1 and 2 and Hypothesis 2. However, the expectation of higher leverage and/or presence of mortgage in non-surviving firms (Hypothesis 1) is not supported by the average values in Table 1 .

\section{Insert Table 1 in about here}

\section{ECONOMETRIC ESTIMATES}

In order to test the predictions and hypotheses about asset stripping, we use the probit model. The model we estimate is:

$$
\begin{aligned}
\operatorname{Pr}_{\left(\text {Survivor }_{\mathrm{it}}=1\right)=} & \phi\left[\alpha_{o}+\alpha_{1} \cdot \text { TFP }_{\mathrm{it}}+\alpha_{2} \cdot \text { InSize }_{\mathrm{it}}+\alpha_{3} \cdot \text { Ownership }_{\mathrm{it}}+\alpha_{4} \cdot \text { Mortgage }_{\mathrm{i}}+\right. \\
& \left.\alpha_{5} \cdot \text { Leverage }_{\mathrm{it}}+\alpha_{6} \cdot\left(\text { Long-term Assets }_{\mathrm{it}} / \text { Assets }_{\mathrm{it}}\right)\right]
\end{aligned}
$$

where $\phi$ is the cumulative normal distribution. The probability of the firm surviving to 2008 depends on the firm's TFP in 1998, 1999 or 2000 (discussed below), logarithm of size (measured by the number of employees in 1998), 1998 ownership structure (given by the percentage of shares owned by the state, private investors, workers, and others), debt in 1998 (measured by a mortgage dummy variable and leverage, defined as debt/(debt + equity)), and 1998 long term assets/total assets ratio.

To obtain an estimate of TFP we follow the mainstream literature and assume that a firm's value added (Y) may be expressed as a Cobb-Douglas function of labor (L) and capital (K):

$$
\mathrm{Y}_{\mathrm{it}}=\mathrm{A}_{\mathrm{it}} \mathrm{L}_{\mathrm{it}}^{\delta} \mathrm{K}_{\mathrm{it}}^{\gamma}
$$

where $\mathrm{A}_{\text {it }}$ is the TFP of a firm $\mathrm{i}$ at time $\mathrm{t}$, calculated as the residual of the estimated production function. We obtain the TFP estimate using a fixed effect (FE) estimator on the annual firm-level observations in 1998-2000, which provides unbiased estimates of absolute TFP levels under the assumption that productivity is close to fixed over that time period. It is worthwhile to note that we are only interested in comparing relative TFP levels across differentially surviving firms, not absolute TFP levels. 
The estimates of the probit model are presented in Table 2. The estimated coefficients in the three columns are based on TFP estimates of individual firms, calculated from the 1998-2000 regression as the firm-specific residuals for 1998, 1999 and 2000, respectively. The values of all other variables correspond to 1998.

As may be seen from Table 2, at the $10 \%$ (two-tail) test significance level, the estimates of the probit model support Prediction 1. In particular, the more productive the firm was before privatization in $1998-2000$, the less likely it was to survive into 2008 . Moreover, at the $1 \%$ test level the estimates in Table 2 support Prediction 2 that larger firms (measured by number of employees in 1998) were more likely to survive into 2008.

On the other hand, the relatively ad hoc Hypotheses 1 and 2 are not supported by our estimates in Table 2. Contrary to Hypothesis 1, the presence of mortgaged property and greater leverage do not have the expected negative effect on survival. In fact, when we use the 2000 TFP estimates (Table 2, column 3), the more leveraged firms are more likely to have survived, perhaps because more leveraged firms were more closely monitored by lenders. Contrary to Hypothesis 2, the ratio of longterm assets to total assets does not have a statistically significant effect on the survival of firms into 2008. We conjecture that the lack of support for Hypotheses 1 and 2 is due to different institutional settings in Russia (which inspired the Hoff-Stiglitz model) and Montenegro. ${ }^{11}$

In sum, the estimates in Table 2 together with the descriptive statistics in Table 1 support the predictions from the Hoff-Stiglitz theoretical model that managers and politically connected individuals in Montenegro were inclined to strip assets, rather than build value, and that they were more likely to do in smaller (less visible) than larger firms.

\footnotetext{
${ }^{11}$ In terms of the control variables, the ownership structure does not appear to have had any direct effect on the survival probability.
} 


\section{CONCLUSIONS}

In this paper, we address a twin theoretical and policy-oriented issue. The theoretical issue is whether and under what conditions mass privatizations are accompanied by asset stripping and, hence, low demand for rule of law. The policy-oriented issue is why a large number of firms disappeared during mass privatization in a rapidly growing economy of Montenegro. Our empirical analysis suggests asset stripping and firm disappearance phenomena were present and related to one another. Moreover, they are consistent with the key predictions of the Hoff and Stiglitz (2004) model.

In interpreting our findings, it is important to note that Montenegro was praised for its progress in privatization during the 1997-2007 period. The value of the sum of the two European Bank for Reconstruction and Development (EBRD) indicators for privatization (small plus large firms) increased from 2 in 1998 to 7 in 2005 (the maximum possible value for both being 8.67 ). ${ }^{12}$ In this period, Montenegro also substantially increased its growth. The average growth rate of GDP in 20012008 was 5 percent, a relatively good performance among the economies in the region. The question that consequently arises is how this positive performance assessment can be reconciled with the fact that so many firms were lost during voucher privatization.

Our analysis shows that asset stripping is a plausible reason for this loss of firms in a boom time. In reality, many firms did not disappear, but in the absence of the rule of law they were appropriated by managers and politically connected individuals who switched the firms to different legal and organizational forms.

Econometrically, we are the first to look at firms that disappeared in the context of mass privatization, as prior studies of privatization of firms generally ignore survival bias. Our results show that more productive firms were liquidated. Prior studies of the performance effects of

\footnotetext{
${ }^{12}$ See, Cerović (2010)
} 
ownership changes during privatization transitions disregard the endogenous exit of higher productivity firms, thus their estimates may suffer from bias. Our finding complements that of Gupta, Ham and Svejnar (2008), who show with Czech data that better performing firms were privatized first and that ignoring this selection leads to biased estimates of the effects of privatization. While Gupta, Ham and Svejnar (2008) show that surviving state-owned firms tend to be worse performers because the better performing firms are privatized first, our complementary results indicate that surviving firms tend to be less productive because the more productive ones disappear on account of asset stripping.

Our results also indicate that one needs to distinguish between true start-ups and liquidated firms that re-appear as de novo (start-up) firms. In particular, one has to be cautious in drawing conclusions about the relative merit of "greenfield and brownfield" investments when the brownfield investments may underperform as a result of asset stripping of the more productive state-owned firms.

An important area for future research concerns the effects of asset stripping in the context of the privatization process on subsequent performance of firms and the economy as a whole. Montenegro for instance mirrored other economies in the region in experiencing solid economic growth in the early-to-mid $2000 \mathrm{~s}$, followed by a recession in the late $2000 \mathrm{~s} .{ }^{13}$ A detailed analysis of recent micro data is needed to assess if asset stripping has had negative consequences on subsequent efficiency and growth.

\footnotetext{
${ }^{13}$ However, some indicators signaled problems early on. For instance, between 2005 and 2009 the unit labor cost in Montenegro rose by $21.7 \%$ relative to that of Austria, while Croatia's and Serbia's unit labor cost (relative to Austria) rose merely $1.8 \%$ and $3.1 \%$, respectively (WIIW, 2010). With this loss of competitive advantage, many Montenegrin firms were hard hit by the global economic recession. Indeed, by some indicators (e.g., budget and current account deficits) recent economic performance may be inferior to that of other economies in the region.
} 


\section{References}

Bevan, Alan, Estrin, Saul, Schaffer, Mark, E., 1999. Determinants of enterprise performance during transition. CERT Discussion Paper 99/03, Herriot-Watt University, Edinburgh.

Bole, Velimir, Prašnikar, Janez, Trobec, Domen, 2012. The debt buildup process: Slovenia versus other European countries. In: Prašnikar, Janez. (Ed.), Comparing companies' success in dealing with external shocks: the case of the Western Balkans, Mediterranean countries and core European countries, Časnik Finance, Ljubljana, pp. 31-42.

Campos, Nauro, P., Giovannoni, Francesco, 2006. The Determinants of Asset Stripping: Theory and Evidence from the Transition Economies, Journal of Law and Economics 49, 681-706.

Carlin, Wendy, Fries, Steven, Schaffer, Mark, E., Seabright, Paul, 2001, Competition and Enterprise Performance in Transition Economies: Evidence from a Cross-Country Survey, CEPR Discussion Paper No. 2840, Centre for Economic Performance at London School of Economics and Political Science, London.

Cerović, Božidar, 2010. Impact of Initial Conditions on Transition Progress: The Case of Montenegro. South-Eastern Europe Journal of Economics 8, 153-171.

Cerović, Božidar, Dragutinović Mitrović, Radmila, 2007. Privatisation Effects: Some Evidence from Serbia. Transition Studies Review 14, 469-487.

Djankov, Simeon, Murrell, Peter, 2002. Enterprise Restructuring in Transition: A Quantitative Survey, Journal of Economic Literature 40, 739-792.

Domadenik, Polona, Prašnikar, Janez, Svejnar, Jan, 2008. Restructuring of firms in transition: ownership, institutions and openness to trade. Journal of International Business Studies 39, 725-746

Estrin, Saul, Hanousek, Jan, Kočenda, Evžen, Svejnar, Jan, 2009. Effects of Privatization and Ownership in Transition Economies. Journal of Economic Literature 47, 699-728.

Ekonomski fakultet Podgorica. 2011. Izveštaj o realizaciji obaveza iz ugovora o privatizaciji privrednih društava koja su privatizirana putem javnog tendera (uvodni dio). Available at http://www.savjetzaprivatizaciju.me/ResourceManager/FileDownload.aspx?rId=954\&rType=1. (Accessed October 10, 2011.) Vlada Crne Gore, Podgorica.

Gregorič, Aleksandra, 2002. Growth in transition economies: the case of Bosnia and Herzegovina. Economic and Business Review 4, 279-308.

Gregurek, Miroslav, 2001. Stupanj i učinci privatizacije u Hrvatskoj. Ekonomski pregled 52, 155188.

Gupta, Nandini, Ham, John., Svejnar, Jan, 2008. Priorities and sequencing in privatization: Evidence from the Czech Republic. European Economic Review 52, 183-208.

Hoff, Karla, Stiglitz, Joseph, E., 2004. After the Big Bang? Obstacles to the Emergence of the Rule of Law in Post-Communist Societies. American Economic Review 94, 753-763. 
Karadžić, Vesna, Jovović, Milorad, 2008. Istraživanje javnog mnenja o privatizaciji u Crnoj Gori. In: Lojpur, Anđelko. (Ed.) Analiza efekata dosadašnje privatizacije u Crnoj Gori. Ekonomski fakultet/Podgorica, No. 7.

Koman, Matjaž, Hadži Vasileva-Markovska, Verica, 2007. Transition firms in Illyria: do workers still manage?: evidence from Macedonian firms. Economic and Business Review 9, 23-45.

Koman, Matjaž, Knežević Cvelbar, Ljubica, Lojpur, Anđelko., Prašnikar, Janez, 2011. Effects of Ownership and Management Changes on Productivity in Privatized Montenegrin Firms. Eastern European Economics 49, 5-26.

Megginson, William, L., Netter, Jeffry, M., 2001 From State to Market: A Survey of Empirical Studies on Privatization, Journal of Economic Literature 39, 321-389.

Prašnikar, Janez, Prašnikar, Vesna, 1986. The Yugoslav Self-Managed Firm in Historical Perspective. Economic and Industrial Democracy 7, 176-190.

Prašnikar, Janez, Svejnar, Jan, 1991. Workers participation in management vs. social ownership and government policies: Yugoslav lessons for transforming socialist economies. Comparative economic studies 4, 27-45.

Prašnikar, Janez, Svejnar, Jan, 2007. Investment, wages and corporate governance during the transition : evidence from Slovenian firms.” In: Estrin, Saul., Kolodko, Grzegorz, W., Uvalić, Milica. (Eds.), Transition and beyond: essays in honor of Mario Nuti, (Studies in economic transition). Basingstoke/New York, pp 149-173.

Savjet za privatizaciju, 2001. Masovna vaučerska privatizacija. Podaci o preduzećima uključenim u MVP. Savjet za privatizaciju, Podgorica .

Shirley, Mary, Walsh, Patrick, 2000. Public versus Private Ownership: The Current State of the Debate. Policy Research Working Paper No. 2420. The World Bank, Washington, DC.

Vijesti, Nezavisni Dnevnik, XV, No 4161, Dailly Press, d.o.o, ISSN 1450-6181, February 4, 2011.

Vukotič Veselin, 2001. Global Development Network South East Europe and the Research Project on Long-term Development of Southeast Europe - Privatization in Montenegro. Available at: http://www.google.si/url?sa=t\&source=web\&cd=1\&ved=0CBcQFjAA\&url=http\%3A\%2F\%2Fbalka n-observatory.net\%2Farchive\%2Fvukotic.pdf\&ei=0BWbTtiINonm4QSsxC6BA\&usg=AFQjCNGLQyX5HT7T5A6DF9thPMMAgC78Vg. (Accessed on October 10, 2011) The Vienna Institute for International Economic Studies, Vienna.

WIIW (The Vienna Institute for International Economic Studies), 2010. Current Analyses and Forecasts. Economics Prospects for Central, East and Southeast Europe No.5. The Vienna Institute for International Economic Studies, Vienna. 
Figure 1: Dual Stable Equilibrium in the Hoff-Stiglitz Model

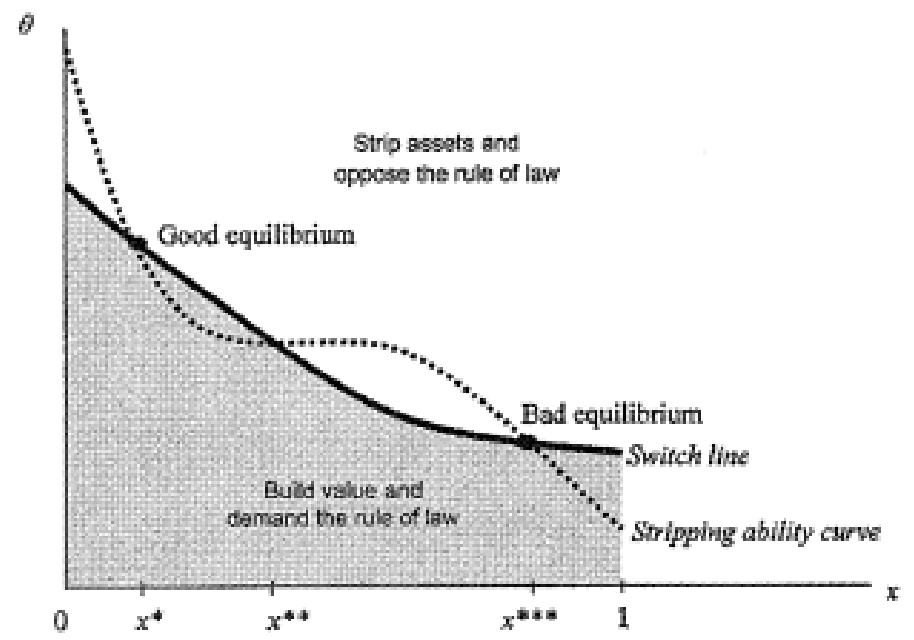

Source: Hoff and Stiglitz (2004). 
Table 1: 1998-2000 Descriptive Statistics for Firms Participating in Mass Voucher Privatization in year 2001

\begin{tabular}{|c|c|c|c|c|c|c|c|}
\hline & \multirow[b]{2}{*}{ VARIABLES } & \multicolumn{2}{|c|}{ NON SURVIVERS } & \multicolumn{2}{|c|}{ SUVIVERS } & \multicolumn{2}{|c|}{ mean-comparison } \\
\hline & & Mean & SD & Mean & SD & t-test & sig \\
\hline & Montly net wage & 100.47 & 93.95 & 157.69 & 122.99 & -6.47 & $* * *$ \\
\hline & Alternative monthly net wage & 97.25 & 50.15 & 114.11 & 67.92 & -3.71 & $* * *$ \\
\hline & Number of Employees & 81.5 & 112.49 & 332.07 & 636.41 & -7.32 & $* * *$ \\
\hline & Labor cost & 174282.2 & 267839 & 1841335 & 5190885.5 & -5.99 & $* * *$ \\
\hline & Revenues from selling goods and services & 726342.9 & 1588774 & 10065847 & 33585957 & -5.19 & *** \\
\hline & Share of revenues in domestic market & 0.93 & 0.64 & 0.93 & 0.55 & -0.13 & \\
\hline & Profit & -154986 & 438283.3 & -3262986 & 23440547 & 2.48 & $* *$ \\
\hline & Leverage $=$ Debt $/($ Debt + Equity $)$ & 0.16 & 0.2 & 0.17 & 0.19 & -0.29 & \\
\hline & Long term assets / Assets & 0.75 & 0.23 & 0.83 & 0.69 & -3.14 & $* * *$ \\
\hline & Debt (long and short term) & 1116186 & 2123548 & 14801226 & 81338369 & -1.99 & *** \\
\hline & Assets & 6035804 & 10677622 & 49892351 & 128432679 & -6.37 & ** \\
\hline & Long term assets & 4810350 & 8667985 & 38707836 & 109526397 & -5.76 & $* * *$ \\
\hline & Fixed capital & 4046879 & 8327085 & 29327437 & 86948565 & -5.39 & $* * *$ \\
\hline & Productivity measure $^{+}$ & 1.45 & 2.76 & 1.12 & 0.66 & 2.12 & $* *$ \\
\hline \multirow{5}{*}{ 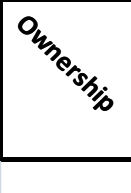 } & State (direct) (\%) & 1.45 & 7.98 & 6.22 & 18.84 & -4.45 & $* * *$ \\
\hline & Private owners (\%)P & 11.12 & 23.03 & 8.94 & 19.6 & 1.3 & \\
\hline & State (direct + indirect) (\%) & 56.73 & 1.38 & 61.64 & 1.14 & -2.73 & *** \\
\hline & Workers (\%) & 28.49 & 0.54 & 27.17 & 0.51 & 1.77 & $*$ \\
\hline & Mortgage (share of companies) & 0.23 & 0.42 & 0.24 & 0.43 & -0.28 & \\
\hline
\end{tabular}

\section{REMARKS:}

All variables are in 2007 euro.

SD is standard deviation.

* significant at $10 \%$; $* *$ significant at $5 \%$; ** significant at $1 \%$

${ }^{+}$The productivity measure is total factor productivity estimated via a fixed effects estimator as described in the text.

Source: Savjet za privatizaciju (2001) and own calculations. 
Table 2: Estimates of the Survival Probit Model for Firms Participating in Mass Voucher Privatization

(The estimated coefficients in the three columns are based on TFP estimates of individual firms, calculated from the 1998-2000 regression of equation (2) as the firm-specific residuals for 1998, 1999 and 2000, respectively.)

\begin{tabular}{|c|c|c|c|c|c|c|c|}
\hline \multicolumn{2}{|c|}{ dependent variable } & \multicolumn{2}{|c|}{ exist_2008 } & \multicolumn{2}{|c|}{ exist_2008 } & \multicolumn{2}{|c|}{ exist_2008 } \\
\hline & & Probabilities & $\begin{array}{c}\text { Average } \\
\text { marginal } \\
\text { effects } \\
(d y / d x)^{+++}\end{array}$ & Probabilities & $\begin{array}{c}\text { Average } \\
\text { marginal } \\
\text { effects } \\
(d y / d x)^{+++}\end{array}$ & Probabilities & $\begin{array}{c}\text { Average } \\
\text { marginal } \\
\text { effects } \\
(d y / d x)^{+++}\end{array}$ \\
\hline \multicolumn{8}{|l|}{ independent variables } \\
\hline \multirow[b]{2}{*}{ Productivity measure $^{+}$} & coef. & -0.466 & -0.154 & -0.41 & -0.138 & -0.362 & -0.121 \\
\hline & st.er. & $0.260^{*}$ & $0.084 *$ & $0.238^{*}$ & $0.078^{*}$ & $0.214^{*}$ & $0.07^{*}$ \\
\hline Mortgage & st.er. & 0.255 & 0.083 & 0.244 & 0.081 & 0.231 & 0.076 \\
\hline \multirow[b]{2}{*}{ Leverage } & coef. & 0.96 & 0.318 & 0.488 & 0.164 & 1.392 & 0.467 \\
\hline & st.er. & 1.082 & 0.355 & 0.928 & 0.311 & $0.841^{*}$ & $0.276 *$ \\
\hline \multirow[b]{2}{*}{ Long term assets / Assets } & coef. & 1.017 & 0.337 & 0.515 & 0.173 & 1.238 & 0.415 \\
\hline & st.er. & 0.944 & 0.309 & 0.832 & 0.279 & 0.788 & 0.259 \\
\hline Number of workers & coef. & 0.002 & 0.0008 & 0.003 & 0.0009 & 0.003 & 0.0009 \\
\hline Ownership: Private investors ${ }^{++++}$ & st.er. & 0.012 & 0.004 & 0.011 & 0.004 & 0.011 & 0.004 \\
\hline \multirow[b]{2}{*}{ Ownership: Workers (all) ${ }^{++++}$} & coef. & -0.001 & -0.0002 & 0.003 & 0.001 & -0.001 & -0.0003 \\
\hline & st.er. & 0.015 & 0.005 & 0.014 & 0.005 & 0.014 & 0.005 \\
\hline \multirow[b]{2}{*}{ Industry dummy: Manufacturing ${ }^{++}$} & coef. & 1 & / & 1 & / & / & / \\
\hline & st.er. & 1 & / & / & / & / & / \\
\hline \multirow[b]{2}{*}{ Industry dummy: Agriculture and Forestry } & coef. & 0.066 & 0.219 & 0.138 & 0.047 & 0.654 & 0.207 \\
\hline & st.er. & 0.672 & 0.222 & 0.67 & 0.224 & 0.548 & 0.155 \\
\hline \multirow[b]{2}{*}{ Industry dummy: Construction } & coef. & -0.135 & -0.045 & -0.358 & -0.120 & -0.053 & -0.012 \\
\hline & st.er. & 0.477 & 0.159 & 0.479 & 0.157 & 0.449 & 0.153 \\
\hline \multirow[b]{2}{*}{ Industry dummy: Transport and Telecomunications } & coef. & -0.187 & -0.063 & -0.087 & -0.029 & 0.007 & 0.002 \\
\hline & st.er. & 0.404 & 0.135 & 0.403 & 0.137 & 0.388 & 0.131 \\
\hline Industry dummy: Trade & coef. & 0.431 & 0.137 & 0.376 & 0.124 & 0.354 & 0.117 \\
\hline \multicolumn{2}{|l|}{ Observations } & 181 & 181 & 196 & 196 & 206 & 206 \\
\hline \multicolumn{8}{|l|}{ REMARKS: } \\
\hline${ }^{*}$ significant at $10 \% ;{ }^{* *}$ significant at $5 \% ;{ }^{* * *}$ significe & nt at $1 \%$ & & & & & & \\
\hline${ }^{+}$The productivity measure is total factor productivi & y estima & ated via a fixe & d effects est & imator as desc & bed in the te & & \\
\hline${ }^{++}$Among industry dummies Manufacturing is used a & a base & (i.e. expresse & ed In a consta & ant term). & & & \\
\hline${ }^{+++} \mathrm{dy} / \mathrm{dx}$ for factor levels is the discrete change fror & the bas & se level. & & & & & \\
\hline${ }^{++++}$Among ownership variablables, share of other $c$ & wnershi & ip is used as a & base. & & & & \\
\hline Source: Savjet za privatizaciju (2001) and own calcule & tions. & & & & & & \\
\hline & & & & & & & \\
\hline
\end{tabular}

